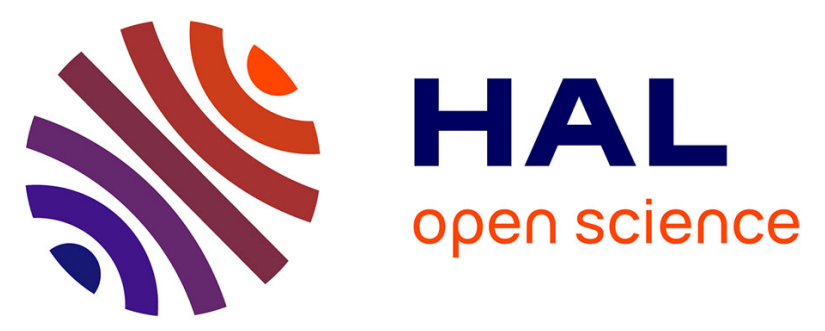

\title{
MicroRNA-30c expression level is an independent predictor of clinical benefit of endocrine therapy in advanced estrogen receptor positive breast cancer
}

F. Germán Rodríguez-González, Anieta M. Sieuwerts, Marcel Smid, Maxime P. Look, Marion E. Meijer-van Gelder, Vanja Weerd, Stefan Sleijfer, John W. M. Martens, John A. Foekens

\section{To cite this version:}

F. Germán Rodríguez-González, Anieta M. Sieuwerts, Marcel Smid, Maxime P. Look, Marion E. Meijer-van Gelder, et al.. MicroRNA-30c expression level is an independent predictor of clinical benefit of endocrine therapy in advanced estrogen receptor positive breast cancer. Breast Cancer Research and Treatment, 2010, 127 (1), pp.43-51. 10.1007/s10549-010-0940-x . hal-00594476

\section{HAL Id: hal-00594476 https://hal.science/hal-00594476}

Submitted on 20 May 2011

HAL is a multi-disciplinary open access archive for the deposit and dissemination of scientific research documents, whether they are published or not. The documents may come from teaching and research institutions in France or abroad, or from public or private research centers.
L'archive ouverte pluridisciplinaire HAL, est destinée au dépôt et à la diffusion de documents scientifiques de niveau recherche, publiés ou non, émanant des établissements d'enseignement et de recherche français ou étrangers, des laboratoires publics ou privés. 
MicroRNA-30c expression level is an independent predictor of clinical benefit of endocrine therapy in advanced estrogen receptor positive breast cancer.

F. Germán Rodríguez-González ${ }^{1,2,3}$, Anieta M. Sieuwerts ${ }^{1}$, Marcel Smid ${ }^{1}$, Maxime P. Look ${ }^{1}$, Marion E. Meijer-van Gelder ${ }^{1}$, Vanja de Weerd ${ }^{1}$, Stefan Sleijfer ${ }^{1}$, John W.M. Martens ${ }^{1}$ and John A. Foekens. ${ }^{1}$

${ }^{1}$ Department of Medical Oncology, Erasmus MC Rotterdam, Josephine Nefkens Institute and Cancer Genomics Centre, Rotterdam, the Netherlands.

${ }^{2}$ Canary Institute for Cancer Research (ICIC), Canary Islands, Spain.

${ }^{3}$ Department of Biochemistry and Physiology, Faculty of Health Sciences, University of Las Palmas de Gran Canaria, Spain.

Running title: MicroRNA-30c predicts tamoxifen resistance.

Key words: Breast Cancer, tamoxifen and miRNAs.

\section{Corresponding author:}

Fco. Germán Rodríguez González, PhD.

Erasmus Medical Center Rotterdam Josephine Nefkens Institute.

Department of Medical Oncology

Dr. Molewaterplein 50, Be 4.02 (lab) / 4.35b (office)

PO BOX 2040, 3000 CA Rotterdam

The Netherlands

+31-10-7044381 (office)

f.rodriguezgonzalez@erasmusmc.nl 


\begin{abstract}
MicroRNAs (miRNAs) are small RNA molecules that modulate gene expression and which have been implicated in cancer. We evaluated whether 5 candidate predictive miRNAs, derived from a pilot study in which 249 miRNAs were assayed, were associated with clinical benefit of tamoxifen therapy in advanced breast cancer. These five miRNAs were measured in an independent series of 246 estrogen receptor (ER)positive primary breast tumors of patients who received tamoxifen for advanced disease by quantitative Real Time PCR. Univariate analysis showed that higher expression levels of hsa-miR-30a-3p, hsa-miR30c and hsa-miR-182 were significantly associated with benefit of tamoxifen treatment and with longer PFS (all $P$-values $<0.01)$. In multivariate analysis, corrected for the traditional predictive factors, only hsa-miRNA-30c was an independent predictor $(P$-value $<0.01)$. Finally, in an attempt to understand the biology connected to this miRNA, Global testing pathway analysis showed an association of hsa-miRNA30c expression with HER and RAC1 signaling pathways.

We identified hsa-miRNA-30c as an independent predictor for clinical benefit of tamoxifen therapy in patients with advanced breast cancer. Assessment of tumor levels and connected pathways could be helpful to improve treatment strategies.
\end{abstract}




\section{Introduction}

Current effective endocrine therapies include treatment with the ER- $\alpha$ antagonist tamoxifen or, more recently, aromatase inhibitors (AIs), that compromise the synthesis of estrogens. Despite their benefit in patients in ER- $\alpha$ positive breast cancer [18] a considerable number of patients with ER-positive breast cancers does not benefit from endocrine therapy due to de novo or acquired resistance [22]. Altered existing [13, 28, 29, 40, 43] or activation of novel signaling pathways [3, 12] are considered to underlie resistant tumors and are thus major obstacles for endocrine therapy to be fully effective [5].

MiRNAs are non-coding, single-stranded RNAs, which in their mature form constitute a novel class of gene regulators [2]. Due to partial sequence homology to the $3^{\prime}$ untranslated region (3' UTR) of target mRNAs, single-stranded mature miRNAs bind to their targets thereby blocking translation or causing mRNA degradation [4].

Altered miRNA expression levels have been described in breast cancer [6, 17, 33], and specific miRNAs have been associated with the occurrence of metastasis and poor prognosis $[1,10,16,24,38]$. In cultured breast cancer cell lines hsa-miRNA-221 and -222 expression can induce tamoxifen resistance due to negative regulation of ER- $\alpha$ or direct targeting of p27Kip1 [27, 44]. These latter studies suggest a role for miRNAs in endocrine therapy resistance in breast cancer. In this work, we have studied in ERpositive beast cancer the association of selected miRNAs with clinical benefit of tamoxifen therapy for advanced disease.

\section{Materials and Methods}

\section{Patients}

The Medical Ethical Committee of the Erasmus Medical Center Rotterdam, the Netherlands, approved our study design (MEC 02.953). This retrospective study used 246 coded, ER protein-positive ( $\geq 10$ fmol/mg protein) primary tumor tissues from patients diagnosed between 1981 and 1995 . This study was conducted in accordance with the Code of Conduct of the Federation of Medical Scientific Societies in the Netherlands (http:/www.fmvv.nl) and where possible adheres to the REMARK criteria for reporting on prognostic/predictive biomarkers [25]. Patients were treated either with breast-conserving surgery $(34 \%)$ or with modified mastectomy (66\%). An axillary dissection was performed in $93 \%$ of the patients $(n=228)$. None of the patients received neoadjuvant therapy or hormonal adjuvant treatment (hormonenaïve). Twenty-eight patients received adjuvant CMF (cyclophosphamide, methotrexate, 5-fluorouracil) 
and 18 patients anthracycline-containing chemotherapy. Relevant clinicopathologic characteristics of the patients and their primary tumor are given in Table 1 . Thirty patients presented with distant metastasis at diagnosis or developed distant metastasis within 1 month after primary surgery (M1-patients). These 30 patients and the 216 M0-patients who developed a recurrence during follow-up (32 patients with localregional relapse; 184 patients with distant metastasis) were treated with tamoxifen (40 mg daily) as first line therapy for advanced disease. Of the $216 \mathrm{M} 0$-patients, the median time between primary surgery and start of therapy was 29 months (range, 2-134 months). At the time of surgical removal of the primary tumor the median age of the patients was 60 years (range, 26-89 years) and at start of tamoxifen therapy for advanced disease 62 years (range, 29-90 years). Response to tamoxifen therapy was defined by standard Union International Contre le Cancer (UICC) criteria [15]. Objective response was observed in 45 patients (12 complete remissions, CR; and 33 partial remissions, PR). Seventy-eight patients experienced an increase in tumor size of $25 \%$ or more, or showed new tumor lesions within 3 months (progressive disease, PD). The remaining 123 patients with no objective response or PD were considered as patients with no change (NC). These patients with $\mathrm{NC}$ were categorized into 112 patients who had NC $>6$ months (defined as stable disease, $\mathrm{SD}$ ) and 11 patients with $\mathrm{NC} \leq 6$ months. The time that $50 \%$ of the patients survived without progression of the disease was for CR: 41 months, PR: 14 months, SD: 14 months, NC $\leq 6$ months: 6 months, and for PD: 3 months. Hundred and fifty-seven patients (64\%) showed clinical benefit $(\mathrm{CR}+\mathrm{PR}+\mathrm{SD})$ of tamoxifen therapy. The median follow-up time of patients alive after surgery was 86 months (range, 10-165 months), and 25 months (range, 1-95 months) after start of tamoxifen therapy. At the end of the follow-up period, 229 patients had developed tumor progression and 181 patients had died.

\section{Tissue processing, RNA isolation, multiplex cDNA synthesis and miRNA quantification}

Tissue inclusion, processing, sectioning and total RNA extraction was done as before [35, 36]. Only ER-positive cases ( $\geq 10 \mathrm{fmol} / \mathrm{mg}$ cytosolic protein or more) determined as described $[8,9]$ were included. As described in detail [10], $50 \mathrm{ng}$ of total RNA was reverse-transcribed using up to 30 different reverse transcription (RT) primers (10 $\mathrm{nM}$ each) in $12 \mu \mathrm{l}$ using the TaqMan MicroRNA Reverse Transcription Kit (ABI) according to the manufacturer's instructions [10]. Using cDNA synthesized from $0.5 \mathrm{ng}$ of total RNA, individual miRNAs were separately quantified in duplicate essentially as described [10] by real-time PCR using individual TaqMan human MicroRNA Assay kits (Table 2). A standard 
curve prepared from a pool of RNA obtained from a randomly selected set of 33 human breast tissues included in this study was added in each cDNA synthesis and PCR run, and the resulting data were used to normalize for in-between experimental variations. In all cDNA synthesis runs a minus RT reaction was always incorporated. PCR efficiency, linearity, and the upper and lower detection limits of each individual miRNA assay was validated [10]. To control for RNA input and integrity, two miRNAs, hsamiR-132 and hsa-miR-374, were used as reference to normalize and quantify miRNA expression levels as previously reported [10].

\section{Statistics}

For statistical computations, STATA statistical package 10.1 (STATA Corp., College Station, TX) was used. Differences in miRNA levels in subgroups of patients were assessed with the MannWhitney U test or Kruskal-Wallis test, including a Wilcoxon-type test for trend. In these tests, patient and tumor characteristics were used as grouping variables. The strengths of the associations between continuous variables were tested with the Spearman rank correlation $\left(\mathrm{r}_{s}\right)$. To reduce the skewness most variables were log or Box-Cox transformed. Logistic regression analysis was used to examine the relation of miRNA levels with clinical benefit of tamoxifen therapy and for the calculation of the odds ratio (OR) and its $95 \%$ confidence interval (CI). The Cox proportional hazard model was used to calculate the hazard ratio (HR) and its 95\% CI in the analyses of PFS. The starting point of PFS being defined as the start of treatment with tamoxifen for recurrence and the endpoint as the first detection of progression of the disease or death. Survival curves were generated using the method of Kaplan and Meier [19] and the log rank test was used to test for differences. A two-sided $P$-value $<0.05$ was considered statistically significant.

\section{Pathways and global testing}

Our Affymetrix microarray gene expression data (entries GSE2034 and GSE5327) were combined with gene expression data from HG-U133-plus2 chips. Data were preprocessed and normalization was performed as previously described [39]. Next, separately for each chip-type, data were normalized before combining the data-sets. Absence of a bias based on the chip-type (the 133A-data and plus 2 data) was checked as described [42]. For 71 of the 246 patients included in this study, we have both miRNA and mRNA expression data available for pathway analysis. The Global Test [14] was used 
(version 4.4.0) to associate Biocarta pathways (http://www.biocarta.com/) to samples expressing high or low amounts of a particular miRNA. For 'high' or 'low' assignment of samples, the 20 samples with the highest and the 20 samples with the lowest expression of a particular miRNA were selected. A $P$-value was considered significant when the false discovery rate (FDR)-adjusted $P$ value of the test $[10]$ as well as $P$-value calculated by 1,000 re-samplings were both $<.05$. The contribution of individual genes in a pathway was evaluated using calculated z-scores [14]; genes with z-scores $>1.96$ were considered significant contributors to the pathway. R version 2.4.1 (http://www.cran.r-project.org) was used to run the Global Test package.

\section{Results}

\section{Identification of candidate miRNAs predictive of clinical benefit}

To identify miRNAs potentially related to the type of response to tamoxifen therapy, we exploited our previously generated data set [10]. This dataset comprised miRNA expression levels of 249 miRNAs of 38 ER-positive breast cancer patients with lymph-node negative disease with welldocumented clinical follow-up. Fifteen of these 38 breast cancer patients, who were all hormone-naïve, experienced a relapse and received tamoxifen monotherapy as first-line treatment for recurrent disease. Ten patients had clinical benefit of this therapy while five did not and progressed within six months. A two-tailed Mann-Whitney test ranked the following five miRNAs, hsa-miR-422a ( $P=0.004)$, hsa-miR30a-3p $(P=0.004)$, hsa-miR-187 $(P=0.005)$, hsa-miR-30c $(P=0.014)$ and hsa-miR-182 $(P=0.027)$, as the most significantly differentially expressed between those patients benefiting from therapy and those who failed therapy.

To independently validate the predictive value of these five putative predictors of benefit of tamoxifen therapy, we measured their expression levels by quantitative real time RT-PCR in 246 ER positive primary tumors of hormone-naïve breast cancer patients who received tamoxifen monotherapy as first-line treatment for advanced disease.

\section{Association of miRNA expression levels with patient and tumor characteristics}

The association of the levels of the five candidate predictive miRNAs with patient and tumor characteristics are summarized in Table 1 . The patient's age was positively correlated with hsa-miR-30c $(P=0.001)$ and hsa-miR-182 $(P=0.009)$ levels. Similarly, these two miRNAs were associated with 
menopausal status $(P=0.036 ; P=0.030$, respectively). The levels of none of the miRNAs analysed were significantly associated other clinical and pathological parameters such as nodal status, tumor size and grade, and disease-free interval.

ER mRNA, PgR mRNA and miRNA levels were analysed as continuous variables. Spearman rank correlation showed significant positive association (all $P<0.001$ ) between the levels of ER mRNA, and those of hsa-miR-30a-3p ( $\left.r_{s}=0.298\right)$, hsa-miR-30c $\left(r_{s}=0.309\right)$, and hsa-miR-182 $\left(r_{s}=0.276\right)$. Furthermore, $\operatorname{PgR}$ mRNA levels were also positively correlated (all $P<0.001)$ with hsa-miR-30a-3p $\left(\mathrm{r}_{\mathrm{s}}=\right.$ $0.444)$, hsa-miR-30c $\left(r_{s}=0.336\right)$ and hsa-miR-182, $\left(r_{s}=0.177\right)$. In contrast, hsa-miR-422a levels were negatively correlated with those of ER $\left(\mathrm{r}_{\mathrm{s}}=-0.134, P=0.036\right)$ and $\operatorname{PgR}\left(\mathrm{r}_{\mathrm{s}}=-0.153, P=0.016\right)$. In addition, hsa-miR-30a-3p expression levels were positively correlated $(P<0.001)$ with those of hsa-miR$30 \mathrm{c}\left(\mathrm{r}_{\mathrm{s}}=0.744\right)$. Hsa-miR-182 $\left(\mathrm{r}_{\mathrm{s}}=0.310\right)$, and hsa-miR-30c levels were correlated with those of hsa$\operatorname{miR}-182\left(r_{s}=0.410\right)$.

\section{Univariate and multivariate analysis for clinical benefit of tamoxifen therapy}

In univariate logistic regression analysis using continuous variables, increasing levels of hsamiR-30a-3p (OR 1.51, 95\% CI 1.16-1.96, $P=0.002)$, hsa-miR-30c (OR 3.87, 95\% CI 2.16-6.94 $P<$ 0.001 ), and hsa-miR-182 (OR 1.54, 95\% CI 1.09-2.16, $P=0.013$ ), were associated with clinical benefit of tamoxifen treatment. No significant associations were observed for hsa-miR-422a or hsa-miR-187 in any of the analyses (not shown). Therefore, these miRNAs are not discussed any further as they were probably false discoveries. In multivariate analysis, when adding the miRNAs separately to the base model comprising the traditional predictive factors (age, menopausal status, dominant site of relapse, disease-free interval and tumor ER and PgR levels), only hsa-miR-30c was significantly associated with clinical benefit (OR 3.15, 95\% CI 1.62-6.12, $P=0.001)$. To express the effect size of the clinical benefit of patients based on the different predictive miRNAs, the patients were categorized into four groups based on their quartile miRNA expression levels. Patients in the fourth quarter with the $25 \%$ highest expression had clinical benefit than those in the first quarter, i.e., $77 \%$ (47 out of 61) versus $48 \%$ (31 out of 64) for hsa-miR-30a-3p, $80 \%$ (49 out of 61) versus 47\% (30 out of 64) for hsa-miR-30c, and 79\% (48 out of 61 ) versus 55\% (34 out of 62) for hsa-miR-182. Similar to the analysis of the miRNAs as a continuous variable, only hsa-miR-30c remained as an independent predictive variable when analyzed as a categorical variable (Table 3). 


\section{Association of miRNA levels with PFS}

The relationship of miRNA levels with PFS was determined with the Cox proportional hazards model and visualized by Kaplan-Meier survival curves using the quarters as mentioned above. Patients in the fourth quarter, with the highest expression levels had the longest PFS for all three miRNAs. Compared with patients with tumor miRNA levels in the first quarter, the HRs for patients in the fourth quarter ranged from 0.47 for hsa-miR-30c, via 0.51 for hsa-miR-30a-3p, to 0.57 for hsa-miR-182 (Figure 1).

\section{Pathways and global testing}

For 71 of the 246 patients Affymetrix (U133A or plus2) transcriptome information was available as well. Using the Global Test [14], we associated biological pathways with the significant miRNAs (Supplementary Table 1). Hsa-miR-30c was found to be the most significantly coupled to "HER, signal transduction and oncology pathway" (comparative $P=0.014$, FDR-adjusted $P=0.007$ ), in which higher ER- $\alpha$ and HER4 expression levels and lower EGFR expression levels were seen in tumors having high hsa-miR-30c expression levels compared with those expressing low levels (Figure 2A). Additionally, hsamiR-30c and hsa-miR-30a-3p were both negatively associated to the "RAC1 cell motility signaling pathway" (comparative $P=0.025$, FDR-adjusted $P=0.015$, and comparative $P=0.016$, FDR-adjusted $P$ $=0.016$, respectively). MRNA expression levels of platelet-derived growth factor receptor $\alpha(\operatorname{PDGFR} \alpha)$, Wiskott-aldrich syndrome protein 1 (WASF1), cdk5 regulatory subunit 1 , (CDK5K1), and chimerin 1 (CHN1) genes were all inversely correlated with the expression levels of these two miRNAs. (Figure 2 B, C).

Hsa-miR-30a-3p was also significantly associated with "Ceramide signaling pathway"

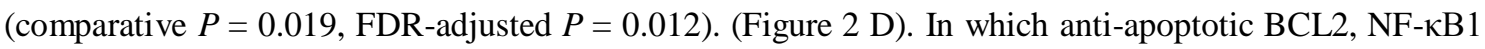
and MAP2K4 were over-expressed in tumors having high versus those having low hsa-miR-30a-3p expression (Supplementary Table 1).

Our analysis did not reveal a significant association of hsa-miR-182 with any of the pathways included in the analysis. 


\section{Discussion}

Given the importance to get better insight into the mechanisms accounting for outcome to hormonal therapy in breast cancer, we explored in this study the association between five putative candidate miRNAs and outcome in ER- $\alpha$ positive breast cancer patients who received tamoxifen therapy for advanced disease. We found an association of high expression levels of hsa-miR-30a-3p, hsa-miR-30c and hsa-miR-182 with clinical benefit and longer PFS. According to published predicted target databases, none of the miRNAs included in this study have the ER mRNA as a target. This suggests that, although indirect effects are possible, the effects of the studied miRNAs on tamoxifen response are not directly related to modulation of ER levels.

To unravel the mechanisms by which these miRNAs affects outcome to tamoxifen, global testing together with gene expression data were used to reveal associations between these miRNAs and biological pathways. In these analyses, the most significant and independent predictor of clinical benefit, hsa-miR-30c, was positively linked to ER- $\alpha$ and negatively to EGFR. Cross-talk between EGFR and ER$\alpha$ has earlier been implicated in tumor cell response to tamoxifen [21, 30, 34]. Furthermore, hsa-miR-30c and the correlated and possibly co-regulated hsa-miR-30a-3p were both negatively correlated to "RAC1 cell motility signaling pathway". The driving growth factor receptor of this pathway, PDGFR $\alpha$, is causally linked to tamoxifen resistance, since we have shown previously [26] that increased expression of PDGFR $\alpha$ allows the human breast cancer cell line ZR-75-1 to grow in the presence of tamoxifen. Downstream Rho/Rac/Cdc42-like GTPases and their activating (RhoGAP) proteins such CHN1 (Chimerin1, also called ARHGAP2) have multiple functions including the modulation of the plasticity of tumor cells $[20,32]$ but there is no link of this with endocrine resistance. Not apparent from the pathway analysis is that another GTPase, RHOBTB3, as well as the GTPase modulator VAV3 are also implicated or associated within tamoxifen resistance [26]. Thus, there is mounting evidence of specific GTPase signaling pathways in modulation of endocrine therapy response. In addition, pathway analysis connects hsa-miR-30a-3p positively to BCL2 mediated cellular survival/ceramide induced apoptosis, which is in line with a favorable role of increased BCL2 expression in breast cancer treated with endocrine therapy [7, 11, 23, 37, 41]. As BCL2 is an ER- $\alpha$ regulated gene, high BCL2 is indicative of an intact ER- $\alpha$ pathway driving tumor growth thereby potentially explaining sensitivity to endocrine therapy [31].

Searching publicly available data bases, it appeared that the highly correlated and highly homologous hsa-miR-30c and -30a share many predicted targets such as PPARGC1B, Makorin-3, 
UBAC1, PTPDC1 (http://microrna.sanger.ac.uk). However, for hsa-miR30-a we quantified the star strand, hsa-miR-30a-3p, which can be also released from the hsa-miR-30a miRNA stemloop. This miRNA targets an entirely different set of genes i.e., POU4F1, ZIC4, FOXJ3, BRCA1 (http://pictar.mdcberlin.de). The putative targets of these miRNAs, however, do not obviously pinpoint to a specific mechanism nor are they connected to the above-mentioned pathways revealed by data mining. As a consequence, thus far the putative targets are not informative and further research is needed to elucidate the exact mechanisms underlying the association of the found miRNAs and outcome to tamoxifen.

In conclusion, this study showed a connection between hsa-miR-30c, hsa-miR-30a-3p and hsamiR-182 expression levels and benefit of conventional endocrine therapy. Only hsa-miR-30c was independent of traditional predictive markers suggesting that measuring this miRNA may have added clinical value. At present these markers are not ready for clinical application. First of all the findings need to be firmly validated in additional independent cohorts, and secondly the current markers on their own are insufficiently strong for clinical decision making and the results should be interpreted as hypothesis generating. Apart from this, the miRNAs revealed to be predictive for outcome to tamoxifen, may be tested for their ability to predict response to aromatase inhibitors as well, the other main type of endocrine therapy currently prescribed. Finally, the pathways connected to these miRNAs as well as their shared predicted target genes may provide new clues for mechanism driving tamoxifen resistance.

\section{Acknowledgements}

This study was financially supported by the Association for International Cancer Research (Grant number 07-0609) and the Netherlands Genomics Initiative (NGI)/Netherlands Organisation for Scientific Research (NWO). 


\section{References}

1. Adams BD, Guttilla IK, White BA (2008) Involvement of microRNAs in breast cancer. Semin Reprod Med 26:522-536.

2. Bartel DP (2004) MicroRNAs: genomics, biogenesis, mechanism, and function. Cell 116:281297.

3. Campbell RA, Bhat-Nakshatri P, Patel NM, Constantinidou D, Ali S, Nakshatri H (2001) Phosphatidylinositol 3-kinase/AKT-mediated activation of estrogen receptor alpha: a new model for anti-estrogen resistance. J Biol Chem 276:9817-9824.

4. Carthew RW, Sontheimer EJ (2009) Origins and Mechanisms of miRNAs and siRNAs. Cell $136: 642-655$.

5. Chen S, Masri S, Wang X, Phung S, Yuan YC, Wu X (2006) What do we know about the mechanisms of aromatase inhibitor resistance? J Steroid Biochem Mol Biol 102:232-240.

6. Cummins JM, He Y, Leary RJ, Pagliarini R, Diaz LA, Jr., Sjoblom T, Barad O, Bentwich Z, Szafranska AE, Labourier E, Raymond CK, Roberts BS, Juhl H, Kinzler KW, Vogelstein B, Velculescu VE (2006) The colorectal microRNAome. Proc Natl Acad Sci U S A 103:3687-3692.

7. dos Santos LG, Lopes-Costa PV, dos Santos AR, Facina G, da Silva BB (2008) Bcl-2 oncogene expression in estrogen receptor-positive and negative breast carcinoma. Eur J Gynaecol Oncol 29:459-461.

8. EORTC Breast Cancer Cooperative Group (1980) Revision of the standards for the assessment of hormone receptors in human breast cancer; report of the second E.O.R.T.C. Workshop, held on 16-17 March, 1979, in the Netherlands Cancer Institute. Eur. J. Cancer 16:1513-1515.

9. Foekens JA, Portengen H, van Putten WL, Peters HA, Krijnen HL, Alexieva-Figusch J, Klijn JGM (1989) Prognostic value of estrogen and progesterone receptors measured by enzyme immunoassays in human breast tumor cytosols. Cancer Res. 49:5823-5828.

10. Foekens JA, Sieuwerts AM, Smid M, Look MP, de Weerd V, Boersma AW, Klijn JG, Wiemer EA, Martens JW (2008) Four miRNAs associated with aggressiveness of lymph node-negative, estrogen receptor-positive human breast cancer. Proc Natl Acad Sci U S A 105:13021-13026. 
11. Gasparini G, Barbareschi M, Doglioni C, Palma PD, Mauri FA, Boracchi P, Bevilacqua P, Caffo O, Morelli L, Verderio P, et al. (1995) Expression of bcl-2 protein predicts efficacy of adjuvant treatments in operable node-positive breast cancer. Clin Cancer Res 1:189-198.

12. Gee JM, Robertson JF, Gutteridge E, Ellis IO, Pinder SE, Rubini M, Nicholson RI (2005) Epidermal growth factor receptor/HER2/insulin-like growth factor receptor signalling and oestrogen receptor activity in clinical breast cancer. Endocr Relat Cancer 12 Suppl 1:S99-S111.

13. Girault I, Bieche I, Lidereau R (2006) Role of estrogen receptor alpha transcriptional coregulators in tamoxifen resistance in breast cancer. Maturitas 54:342-351.

14. Goeman JJ, van de Geer SA, de Kort F, van Houwelingen HC (2004) A global test for groups of genes: testing association with a clinical outcome. Bioinformatics 20:93-99.

15. Hayward JL, Carbone PP, Heuson JC, Kumaoka S, Segaloff A, Rubens RD (1977) Assessment of response to therapy in advanced breast cancer: a project of the Programme on Clinical Oncology of the International Union Against Cancer, Geneva, Switzerland. Cancer 39:12891294.

16. Huang GL, Zhang XH, Guo GL, Huang KT, Yang KY, Hu XQ (2008) [Expression of microRNA-21 in invasive ductal carcinoma of the breast and its association with phosphatase and tensin homolog deleted from chromosome expression and clinicopathologic features.]. Zhonghua Yi Xue Za Zhi 88:2833-2837.

17. Iorio MV, Ferracin M, Liu CG, Veronese A, Spizzo R, Sabbioni S, Magri E, Pedriali M, Fabbri M, Campiglio M, Menard S, Palazzo JP, Rosenberg A, Musiani P, Volinia S, Nenci I, Calin GA, Querzoli P, Negrini M, Croce CM (2005) MicroRNA gene expression deregulation in human breast cancer. Cancer Res 65:7065-7070.

18. Jaiyesimi IA, Buzdar AU, Decker DA, Hortobagyi GN (1995) Use of tamoxifen for breast cancer: twenty-eight years later. J Clin Oncol 13:513-529.

19. Kaplan EL, Meier P (1958) Non-parametric estimation from incomplete observations. J Am Stat Assoc 53:457-481.

20. Katoh Y, Katoh M (2004) Identification and characterization of ARHGAP27 gene in silico. Int J Mol Med 14:943-947. 
21. Klijn JG, Berns PM, Schmitz PI, Foekens JA (1992) The clinical significance of epidermal growth factor receptor (EGF-R) in human breast cancer: a review on 5232 patients. Endocr Rev $13: 3-17$.

22. Lewis JS, Jordan VC (2005) Selective estrogen receptor modulators (SERMs): mechanisms of anticarcinogenesis and drug resistance. Mutat Res 591:247-263.

23. Linke SP, Bremer TM, Herold CD, Sauter G, Diamond C (2006) A multimarker model to predict outcome in tamoxifen-treated breast cancer patients. Clin Cancer Res 12:1175-1183.

24. Ma L, Teruya-Feldstein J, Weinberg RA (2007) Tumour invasion and metastasis initiated by microRNA-10b in breast cancer. Nature 449:682-688.

25. McShane LM, Altman DG, Sauerbrei W, Taube SE, Gion M, Clark GM (2006) REporting recommendations for tumor MARKer prognostic studies (REMARK). Breast Cancer Res Treat 100:229-235.

26. Meijer D, van Agthoven T, Bosma PT, Nooter K, Dorssers LC (2006) Functional screen for genes responsible for tamoxifen resistance in human breast cancer cells. Mol Cancer Res 4:379386.

27. Miller TE, Ghoshal K, Ramaswamy B, Roy S, Datta J, Shapiro CL, Jacob S, Majumder S (2008) MicroRNA-221/222 confers tamoxifen resistance in breast cancer by targeting p27Kip1. J Biol Chem 283:29897-29903.

28. Murphy LC, Leygue E, Niu Y, Snell L, Ho SM, Watson PH (2002) Relationship of coregulator and oestrogen receptor isoform expression to de novo tamoxifen resistance in human breast cancer. Br J Cancer 87:1411-1416.

29. Murphy LC, Weitsman GE, Skliris GP, Teh EM, Li L, Peng B, Davie JR, Ung K, Niu YL, Troup S, Tomes L, Watson PH (2006) Potential role of estrogen receptor alpha (ERalpha) phosphorylated at Serine118 in human breast cancer in vivo. J Steroid Biochem Mol Biol 102:139-146.

30. Osborne CK, Schiff R (2003) Growth factor receptor cross-talk with estrogen receptor as a mechanism for tamoxifen resistance in breast cancer. Breast 12:362-367.

31. Perillo B, Sasso A, Abbondanza C, Palumbo G (2000) 17beta-estradiol inhibits apoptosis in MCF-7 cells, inducing bcl-2 expression via two estrogen-responsive elements present in the coding sequence. Mol Cell Biol 20:2890-2901. 
32. Sanz-Moreno V, Gadea G, Ahn J, Paterson H, Marra P, Pinner S, Sahai E, Marshall CJ (2008) Rac activation and inactivation control plasticity of tumor cell movement. Cell 135:510-523.

33. Scott GK, Goga A, Bhaumik D, Berger CE, Sullivan CS, Benz CC (2007) Coordinate suppression of ERBB2 and ERBB3 by enforced expression of micro-RNA miR-125a or miR125b. J Biol Chem 282:1479-1486.

34. Shou J, Massarweh S, Osborne CK, Wakeling AE, Ali S, Weiss H, Schiff R (2004) Mechanisms of tamoxifen resistance: increased estrogen receptor-HER2/neu cross-talk in ER/HER2-positive breast cancer. J Natl Cancer Inst 96:926-935.

35. Sieuwerts AM, Look MP, Meijer-van Gelder ME, Timmermans M, Trapman AM, Garcia RR, Arnold M, Goedheer AJ, de Weerd V, Portengen H, Klijn JG, Foekens JA (2006) Which cyclin E prevails as prognostic marker for breast cancer? Results from a retrospective study involving 635 lymph node-negative breast cancer patients. Clin Cancer Res 12:3319-3328.

36. Sieuwerts AM, Meijer-van Gelder ME, Timmermans M, Trapman AM, Garcia RR, Arnold M, Goedheer AJ, Portengen H, Klijn JG, Foekens JA (2005) How ADAM-9 and ADAM-11 differentially from estrogen receptor predict response to tamoxifen treatment in patients with recurrent breast cancer: a retrospective study. Clin Cancer Res 11:7311-7321.

37. Silvestrini R, Benini E, Veneroni S, Daidone MG, Tomasic G, Squicciarini P, Salvadori B (1996) p53 and bcl-2 expression correlates with clinical outcome in a series of node-positive breast cancer patients. J Clin Oncol 14:1604-1610.

38. Tavazoie SF, Alarcon C, Oskarsson T, Padua D, Wang Q, Bos PD, Gerald WL, Massague J (2008) Endogenous human microRNAs that suppress breast cancer metastasis. Nature 451:147152.

39. Wang Y, Klijn JG, Zhang Y, Sieuwerts AM, Look MP, Yang F, Talantov D, Timmermans M, Meijer-van Gelder ME, Yu J, Jatkoe T, Berns EM, Atkins D, Foekens JA (2005) Geneexpression profiles to predict distant metastasis of lymph-node-negative primary breast cancer. Lancet 365:671-679.

40. Weis KE, Ekena K, Thomas JA, Lazennec G, Katzenellenbogen BS (1996) Constitutively active human estrogen receptors containing amino acid substitutions for tyrosine 537 in the receptor protein. Mol Endocrinol 10:1388-1398. 
41. Yang Q, Sakurai T, Yoshimura G, Suzuma T, Umemura T, Nakamura M, Nakamura Y, Mori I, Kakudo K (2003) Prognostic value of Bcl-2 in invasive breast cancer receiving chemotherapy and endocrine therapy. Oncol Rep 10:121-125.

42. Yu JX, Sieuwerts AM, Zhang Y, Martens JW, Smid M, Klijn JG, Wang Y, Foekens JA (2007) Pathway analysis of gene signatures predicting metastasis of node-negative primary breast cancer. BMC Cancer 7:182.

43. Yudt MR, Vorojeikina D, Zhong L, Skafar DF, Sasson S, Gasiewicz TA, Notides AC (1999) Function of estrogen receptor tyrosine 537 in hormone binding, DNA binding, and transactivation. Biochemistry 38:14146-14156.

44. Zhao JJ, Lin J, Yang H, Kong W, He L, Ma X, Coppola D, Cheng JQ (2008) MicroRNA221/222 negatively regulates estrogen receptor alpha and is associated with tamoxifen resistance in breast cancer. J Biol Chem 283:31079-31086. 
Legends to the figures

Figure 1. Kaplan Meier survival curves.

For PFS analysis, samples were divided in quarters $\left(\mathrm{Q}_{1}-\mathrm{Q}_{4}\right)$ based on the quartile levels of hsa-miR-30a3p (A), hsa-miR-30c (B), and hsa-miR-182 (C). Patients at risk at 12 and 24 month time intervals are indicated at the bottom of each graph.

Figure 2. Pathways associated with the tumor subgroup having high versus low hsa-miR-30c (A, B) or hsa-miR-30a-3p (C, D).

The color of a bar represents positive (red) or negative (green) association.

The number of horizontal markers in a bar indicates the significance and the height of a bar the contribution of a gene to the pathway.

Table 1. Associations of biological factors with clinico pathological factors

\begin{tabular}{|c|c|c|c|c|c|c|}
\hline \multirow{2}{*}{ Charactristics } & \multicolumn{6}{|c|}{ Median miRs levels (interquartile range) after normalization to the housekeeper $n$} \\
\hline & Patients & hsa-miR-30a-3p & hsa-miR-30c & hsa-miR-182 & hsa-miR-187 & hsa-I \\
\hline \multicolumn{7}{|l|}{ Age (years) } \\
\hline$\leq 55$ & 92 & $0.59(0.81)$ & $0.94(0.77)$ & $0.80(0.75)$ & $0.19(0.70)$ & \\
\hline $56-70$ & 90 & $0.68(1.00)$ & $1.01(0.95)$ & $1.03(1.18)$ & $0.19(0.61)$ & \\
\hline \multirow[t]{2}{*}{$>70$} & 64 & $0.76(1.80)$ & $1.34(1.23)$ & $0.95(1.12)$ & $0.26(1.31)$ & \\
\hline & & $P=0.092^{+}$ & $P=0.001^{7}$ & $P=0.009^{\mp}$ & $P=0.064^{\mp}$ & \\
\hline \multicolumn{7}{|l|}{ Menopausal status } \\
\hline Premenopausal & 59 & $0.60(0.80)$ & $0.87(0.69)$ & $0.78(0.81)$ & $0.15(0.67)$ & \\
\hline \multirow{2}{*}{ Postmenopausal } & 187 & $0.70(1.17)$ & $1.08(1.07)$ & $0.96(1.08)$ & $0.21(0.79)$ & \\
\hline & & $P=0.257^{4}$ & $P=0.036^{\prime}$ & $P=0.030^{\prime}$ & $P=0.159$ & \\
\hline \multicolumn{7}{|l|}{ Dominant site of relapse } \\
\hline Local regional relapse & 32 & $0.48(0.73)$ & $0.88(0.97)$ & $0.81(0.43)$ & $0.22(0.67)$ & \\
\hline Bone & 128 & $0.70(1.27)$ & $1.05(0.81)$ & $1.01(0.99)$ & $0.22(0.81)$ & \\
\hline \multirow[t]{2}{*}{ Visceral } & 86 & $0.56(0.85)$ & $1.01(1.10)$ & $0.91(1.34)$ & $0.20(0.63)$ & \\
\hline & & $P=0.318^{8}$ & $P=0.816^{8}$ & $P=0.131^{8}$ & $P=0.623^{8}$ & \\
\hline \multicolumn{7}{|c|}{ Disease-free interval (months) } \\
\hline$\leq 12$ & 64 & $0.51(0.68)$ & $0.88(0.89)$ & $0.91(0.85)$ & $0.21(1.37)$ & \\
\hline $13-36$ & 108 & $0.74(1.13)$ & $1.05(0.98)$ & $0.94(1.14)$ & $0.18(0.48)$ & \\
\hline \multirow[t]{2}{*}{$>36$} & 74 & $0.86(1.35)$ & $1.14(0.99)$ & $1.01(0.91)$ & $0.22(0.84)$ & \\
\hline & & $P=0.173^{\S}$ & $P=0.163^{\S}$ & $P=0.945^{\S}$ & $P=0.219^{\S}$ & \\
\hline \multicolumn{7}{|l|}{ Tumor Size $(\mathbf{c m})^{\top}$} \\
\hline$\leq 2$ & 65 & $0.60(1.41)$ & $0.98(0.93)$ & $1.01(0.78)$ & $0.19(0.83)$ & \\
\hline $2-5$ & 146 & $0.66(0.99)$ & $1.02(0.85)$ & $0.90(1.08)$ & $0.21(0.63)$ & \\
\hline$>5$ & 35 & $0.66(0.89)$ & $1.28(1.05)$ & $0.91(1.50)$ & $0.09(0.54)$ & \\
\hline
\end{tabular}




\begin{tabular}{|c|c|c|c|c|c|}
\hline & & $P=0.934^{8}$ & $P=0.506^{8}$ & $P=0.912^{8}$ & $P=0.215^{8}$ \\
\hline \multicolumn{6}{|l|}{ Grade $^{\top}$} \\
\hline Poor & 139 & $0.70(1.06)$ & $1.02(0.97)$ & $0.89(0.89)$ & $0.23(0.87)$ \\
\hline Unknown & 77 & $0.65(0.81)$ & $1.05(0.75)$ & $1.02(0.95)$ & $0.19(0.62)$ \\
\hline Good/moderate & 30 & $0.49(1.52)$ & $1.14(1.46)$ & $0.90(0.86)$ & $0.22(0.71)$ \\
\hline \multicolumn{6}{|l|}{ Nodal status ${ }^{\top}$} \\
\hline No & 96 & $0.74(1.01)$ & $1.04(0.93)$ & $1.00(1.02)$ & $0.19(0.68)$ \\
\hline N1-3 & 59 & $0.70(1.22)$ & $1.08(1.12)$ & $0.82(1.03)$ & $0.22(0.66)$ \\
\hline$N>3$ & 76 & $\begin{array}{l}0.46(0.90) \\
P=0.288^{8}\end{array}$ & $\begin{array}{l}0.94(0.86) \\
P=0.671^{8}\end{array}$ & $\begin{array}{l}0.84(0.77) \\
P=0.294^{8}\end{array}$ & $\begin{array}{l}0.18(0.55) \\
P=0.522^{8}\end{array}$ \\
\hline
\end{tabular}

*At start tamoxifen treatment for recurrent disease

† At diagnosis

\$Spearman

${ }^{\S}$ Kruskal-Wallis test

"II Mann Whitney U

Table 2. MicroRNA assays used in the study (Applied Biosystems).

\begin{tabular}{lccc}
\multicolumn{1}{c}{ MicroRNA } & Assay number & ID & Target Sequence \\
\hline hsa-miR-30a-3p & 4373062 & 416 & CUUUCAGUCGGAUGUUUGAGC \\
hsa-miR-30c & 4373060 & 419 & UGUAAACAUCCUACACUCUCAGC \\
hsa-miR-182 & 4373271 & 597 & UUUGGCAAUGGUAGAACUCACA \\
hsa-miR-187 & 4373111 & 487 & UCGUGUCUUGUGUUGCAGCCG \\
hsa-miR-422a & 4395408 & 2297 & ACUGGACUUAGGGUCAGAAGGC \\
\hline
\end{tabular}

Table 3. Univariate and multivariate analysis for clinical benefit of tamoxifen therapy for metastatic breast cancer

\begin{tabular}{|c|c|c|c|c|c|}
\hline \multirow[b]{2}{*}{ Factor } & \multirow[b]{2}{*}{ Patients } & \multirow[b]{2}{*}{ Clinical benefit (\%) } & \multicolumn{2}{|c|}{ Univariate analysis } & \multirow{2}{*}{$\begin{array}{l}\text { Multivariate ana } \\
\text { OR }(95 \% \mathrm{Cl})\end{array}$} \\
\hline & & & OR (95\% Cl) & $P$ & \\
\hline All patients & 246 & 64 & & & \\
\hline $\begin{array}{l}\text { Age (years) } \\
\quad \leq 55 \\
\quad 56-70 \\
>70\end{array}$ & $\begin{array}{l}92 \\
90 \\
64\end{array}$ & $\begin{array}{l}55 \\
66 \\
73\end{array}$ & $\begin{array}{l}1 \\
1.53(0.84-2.78) \\
2.22(1.11-4.43)\end{array}$ & $\begin{array}{l}0.163 \\
0.023\end{array}$ & $\begin{array}{l}1 \\
0.92(0.36-2.32) \\
1.60(0.60-4.29)\end{array}$ \\
\hline $\begin{array}{c}\text { Menopausal status } \\
\text { Premenopausal } \\
\text { Postmenopausal }\end{array}$ & $\begin{array}{c}59 \\
187\end{array}$ & $\begin{array}{l}53 \\
67\end{array}$ & $\begin{array}{l}1 \\
1.87(1.03-3.38)\end{array}$ & 0.040 & $\begin{array}{l}1 \\
1.33(0.53-3.38)\end{array}$ \\
\hline $\begin{array}{l}\text { Dominant site of relapse } \\
\text { Local regional relapse } \\
\text { Bone } \\
\text { Visceral }\end{array}$ & $\begin{array}{c}32 \\
128 \\
86\end{array}$ & $\begin{array}{l}72 \\
59 \\
67\end{array}$ & $\begin{array}{l}1 \\
0.57(0.25-1.33) \\
0.81(0.33-1.98)\end{array}$ & $\begin{array}{l}0.196 \\
0.644\end{array}$ & $\begin{array}{l}1 \\
0.54(0.21-1.38) \\
0.65(0.24-1.77)\end{array}$ \\
\hline $\begin{array}{l}\text { Disease-free interval (mo } \\
\quad \leq 12 \\
\quad 13-36 \\
>36\end{array}$ & $\begin{array}{c}64 \\
108 \\
74\end{array}$ & $\begin{array}{l}41 \\
70 \\
74\end{array}$ & $\begin{array}{l}1 \\
3.47(1.82-6.63) \\
4.23(2.06-8.71)\end{array}$ & $\begin{array}{l}<0.001 \\
<0.001\end{array}$ & $\begin{array}{l}1 \\
3.93(1.95-7.91) \\
4.37(2.00-9.57)\end{array}$ \\
\hline $\begin{array}{l}\text { ER } \\
\text { PgR }\end{array}$ & $\begin{array}{l}246 \\
246\end{array}$ & $\begin{array}{l}64 \\
64\end{array}$ & $\begin{array}{l}1.29(1.13-1.47) \\
1.13(0.98-1.31)\end{array}$ & $\begin{array}{r}<0.001 \\
0.083\end{array}$ & $\begin{array}{l}1.29(1.10-1.50) \\
1.03(0.87-1.22)\end{array}$ \\
\hline
\end{tabular}

Additions to the bas 
hsa-miR-30a-3p ${ }^{\mp}$

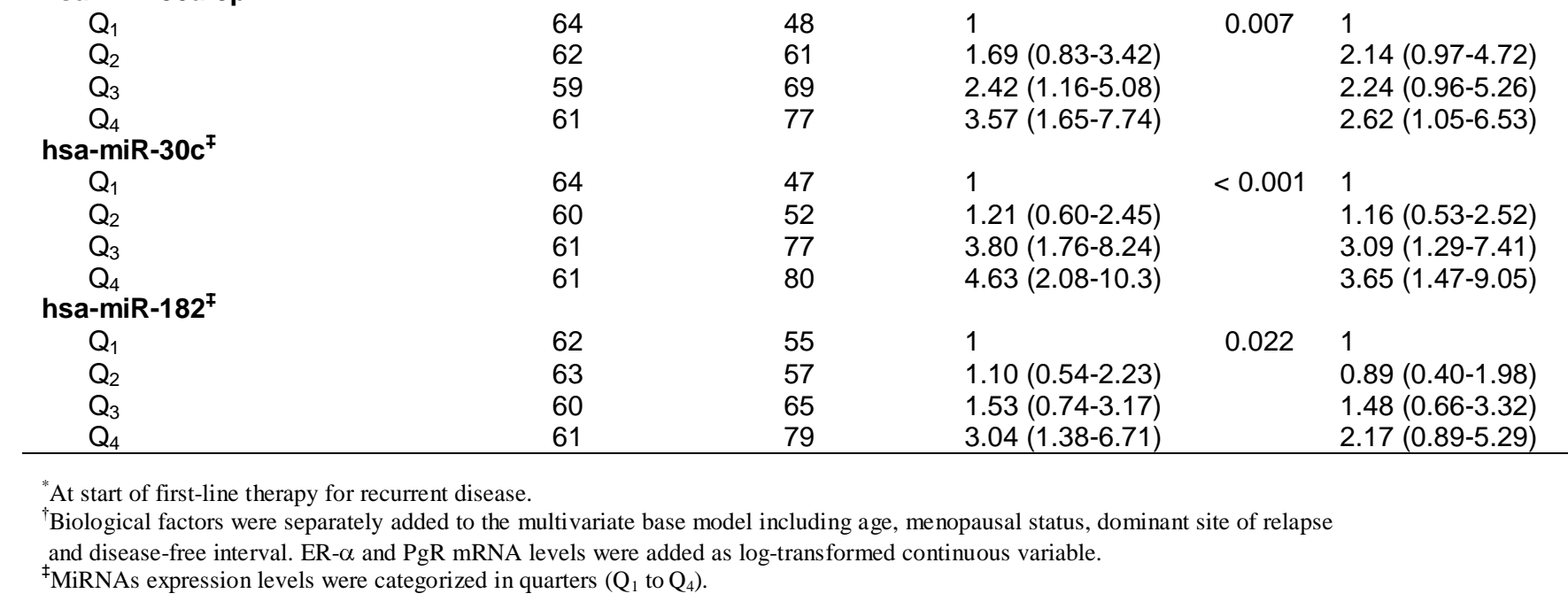

